\title{
Long-term results of combined treatment of patients with early breast cancer after conserving therapy
}

\section{Odległe wyniki skojarzonego leczenia chorych z wczesnym rakiem piersi po leczeniu oszczędzającym}

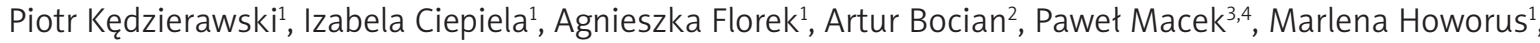 \\ Stanisław Góźdź5,6 \\ ${ }^{1}$ Clinic of Radiotherapy, Holycross Cancer Centre, Kielce, Poland \\ Head of the Clinic: Jacek Sadowski MD \\ ${ }^{2}$ Clinic of Oncological Surgery, Holycross Cancer Centre, Kielce, Poland \\ Head of the Clinic: Jacek Haduch MD \\ ${ }^{3}$ Department of Epidemiology and Cancer Control, Holycross Cancer Centre, Kielce, Poland \\ Head of the Department: Paweł Macek PhD \\ ${ }^{4}$ School of Economics, Law and Medical Sciences, Kielce, Poland \\ Head of the School: Grzegorz Gałuszka PhD \\ ${ }^{5}$ Clinic of Clinical Oncology, Holycross Cancer Centre, Kielce, Poland \\ Head of the Clinic: Prof. Stanisław Góźdź MD, PhD \\ ${ }^{6}$ Department of Cancer Prevention and Epidemiology, Institute of Public Health, Faculty of Medicine and Health Sciences, \\ Jan Kochanowski University, Kielce, Poland \\ Head of the Department: Prof. Stanisław Góźdź MD, PhD
}

Key words: breast cancer, cosmetic effect, conserving treatment.

Słowa kluczowe: rak piersi, efekt kosmetyczny, leczenie oszczędzające.

\begin{abstract}
Introduction: Mastectomy was the most frequently used method of surgical treatment of patients with breast cancer in the Kielce Region. With the opening of the Surgical Oncology Clinic and the Department of Radiotherapy in the Holycross Cancer Centre, a larger number of patients could undergo breast-conserving therapy.

Aim of the research: The objective of the study was evaluation of the remote outcome of treatment of patients with breast cancer after conserving therapy.

Material and methods: During the period 2001-2005, in the Holycross Cancer Centre, 65 women with early-stage breast cancer underwent breast-conserving therapy. The patients were subjected to combined treatment. The total period of observation was from 105 to 143 months; median 113 months. In statistical analysis the distribution of the investigated variables was examined using the Kolmogorov-Smirnov test and Lillefors test. The significance of the differences between the variables analysed was tested by means of the Mann-Whitney $U$ test. The probability of survival without symptoms of the disease was estimated by the Kaplan-Meier method. The cosmetic outcome was evaluated based on individual medical observations and a questionnaire developed at the Department of Radiotherapy.

Results and conclusions: Relapse of the disease was noted in $5(8 \%)$ patients. Local recurrence occurred in $2(3 \%)$ patients. In the analysed group, the 2-, 3-, 5-, and 10-year survival rates without symptoms were $98.5 \%, 96.9 \%, 95.4 \%$, and $95.4 \%$, respectively. No statistically significant differences were found between the groups of patients with and without cancer. In the majority of patients, after many-year observation, the cosmetic outcome is good.
\end{abstract}

\section{Streszczenie}

Wprowadzenie: Mastektomia była najcześciej stosowaną metoda leczenia chirurgicznego chorych na raka piersi w województwie świętokrzyskim. Wraz z otwarciem w Świętokrzyskim Centrum Onkologii Kliniki Chirurgii Onkologicznej i Zakładu Radioterapii oraz udoskonaleniem metod diagnostycznych większa liczba pacjentek może być poddana leczeniu z zaoszczędzeniem piersi.

Cel pracy: Ocena odległych wyników leczenia chorych na raka piersi po leczeniu oszczędzającym.

Materiał i metody: W Świętokrzyskim Centrum Onkologii w Kielcach w latach 2001-2005 leczono w sposób oszczędzający 65 kobiet chorych na raka piersi we wczesnym stopniu zaawansowania. Chore poddano leczeniu skojarzonemu. Całko- 
wity czas obserwacji wynosił 105-143 miesięcy, a mediana 113 miesięcy. W analizie statystycznej ocenę rozkładu badanych zmiennych przeprowadzono testami Kolmogorowa-Smirnowa i Lilleforsa. Istotność różnic analizowanych zmiennych sprawdzono testem U Manna-Whitneya. Prawdopodobieństwo przeżycia bez objawów choroby oszacowano metodą Kaplana-Meiera. Oceniono także efekt kosmetyczny po leczeniu na podstawie indywidualnych obserwacji lekarskich i ankiety przygotowanej w Zakładzie Radioterapii.

Wyniki i wnioski: Nawrót choroby stwierdzono u 5 (8\%) chorych. Wznowa miejscowa wystąpiła u 2 (3\%) chorych. Przeżycia bezobjawowe 2-, 3-, 5- i 10-letnie w analizowanej grupie wyniosły odpowiednio 98,5\%, 96,9\%, 95,4\% i 95,4\%. Nie stwierdzono istotnych różnic pomiędzy grupami chorych bez nawrotu i z nawrotem raka. U większości chorych w wieloletniej obserwacji efekt kosmetyczny jest dobry.

\section{Introduction}

Mastectomy was the most frequently used method of surgical treatment of patients with breast cancer in the Kielce Region. With the opening of the Surgical Oncology Clinic (2000) and the Department of Radiotherapy (1997) in the Holycross Cancer Centre, an increasingly large group of patients could undergo breastconserving therapy. Many studies have confirmed that conserving therapy is equivalent to mastectomy with respect to local control and long-term survival, which provided an incentive for more frequent use of this method [1-6]. At that time, in accordance with the recommendations, in patients with early-stage breast cancer the conserving therapy consisted of resection of the tumour with a margin (lumpectomy or quadrantectomy) and dissection of the regional lymph nodes. After surgical treatment, the patients underwent irradiation in the breast area and, when metastases were diagnosed, also in the area of regional lymph nodes. In the case of indications for systemic therapy, radiotherapy was postponed until the completion of chemotherapy $[7,8]$. The entire process of treatment was carried out in the Holycross Cancer Centre. The patients were qualified for this form of therapy very thoroughly, so the examined group is not very large.

\section{Aim of the research}

The objective of the study is evaluation of the outcomes of treatment by many-year observation of patients with early-stage breast cancer, who had undergone combined therapy in the Holycross Cancer Centre during the period 2001-2005.

\section{Material and methods}

The analysed group included 65 women with breast cancer, aged 46-91, mean age 63 years. Table 1 presents the clinical characteristics of patients and type of therapy applied. Based on the clinical assessment and imaging tests, stage I cancer was diagnosed in $58(89 \%)$ patients and stage IIA in 7 (11\%).

The patients were subjected to conserving therapy (quadrantectomy or lumpectomy, and axillary lymphadenectomy). Based on histopathological examination of the tissue material, the degree of pathological advancement of cancer stage IA was found in $48(74 \%)$ patients, stage IIA in 16 (25\%), and stage IIIA in $1(1 \%)$ patient. In the majority of patients, microscopic examination confirmed ductal carcinoma (89\%). In 88\% of the women in the study no metastases were observed into the axillary lymph nodes, in the surgical material. After surgical treatment the patients were qualified for adjuvant therapy. The indications for systemic therapy were: metastases to the regional lymph nodes, tumour diameter of over $1 \mathrm{~cm}$, high-grade malignancy (G2, G3), and negative steroid receptors. Chemotherapy according to the cyclophosphamide, methotrexate, fluorouracil (CMF) regimen was most frequently applied (35 patients). In the case of qualification for chemotherapy, radiotherapy was used after the completion of systemic therapy. Hormonal therapy was used in $68 \%$ of patients. Tamoxifen was most frequently applied: in $40 \%$ of patients, followed by tamoxifen and switching to an aromatase inhibitor - in $25 \%$ of patients. In four patients the HER 2 was positive. Therapy with trastuzumab was not applied.

Conformal radiotherapy was used in 61 patients, 53 received breast irradiation, and eight patients, in addition to breast irradiation, underwent regional nodal irradiation due to metastases diagnosed in histopathological examination. Two dose-fractionation regimens were applied: 39 patients were irradiated in a shortened treatment time 42,5 Gy/17 fractions, 22 with conventional dose-fractionation - 50 Gy/25 fractions. The conventional dose-fractionation was used in patients in whom, apart from the breast, the regional lymphatic system was also irradiated. An increased radiation dose to the tumour bed was applied in nearly all the irradiated patients (60). All patients completed radiotherapy within the planned time.

Patients who had undergone surgical treatment were trained in the prevention of swelling. The Department of Rehabilitation at the Holycross Cancer Centre carried out rehabilitation procedures in accordance with the valid recommendations.

\section{Statistical analysis}

In statistical analysis, basic statistics were calculated: arithmetic mean, standard deviation, median, as well as lower and upper quartiles. The distribution of the investigated variables was examined using the Kolmogorov-Smirnov test and Lillefors test. The significance of the differences between the variables analysed was tested by means of the Mann-Whitney $U$ test. 
Table 1. Clinical characteristics of 65 patients

\begin{tabular}{|c|c|}
\hline Parameter & Result \\
\hline Patients & $65(100 \%)$ \\
\hline \multicolumn{2}{|l|}{ Age [years]: } \\
\hline Mean & 63 \\
\hline Min. & 58 \\
\hline Max. & 67 \\
\hline \multicolumn{2}{|l|}{ Breast: } \\
\hline Right & $4(37 \%)$ \\
\hline Left & $41(63 \%)$ \\
\hline \multicolumn{2}{|l|}{ Tumour localisation: } \\
\hline Lateral & $40(62 \%)$ \\
\hline Medial & $16(25 \%)$ \\
\hline Other & $9(13 \%)$ \\
\hline \multicolumn{2}{|l|}{ Clinical stage: } \\
\hline I & $58(89 \%)$ \\
\hline II & $7(11 \%)$ \\
\hline \multicolumn{2}{|l|}{ Pathological stage: } \\
\hline 1 & $48(74 \%)$ \\
\hline IIA & $16(25 \%)$ \\
\hline IIIA & $1(1 \%)$ \\
\hline \multicolumn{2}{|l|}{ No. of excised nodes: } \\
\hline Mean & 15 \\
\hline Min. & 11 \\
\hline Max. & 19 \\
\hline \multicolumn{2}{|l|}{ No. of involved nodes: } \\
\hline 0 & 57 (88\%) \\
\hline $1-3$ & $7(11 \%)$ \\
\hline$>3$ & $1(1 \%)$ \\
\hline \multicolumn{2}{|c|}{ Histopathological type of tumour: } \\
\hline Carcinoma ductale & $58(89 \%)$ \\
\hline Carcinoma lobulare & $2(3 \%)$ \\
\hline Other types & $5(8 \%)$ \\
\hline \multicolumn{2}{|c|}{ Grade of histological malignancy: } \\
\hline G1 & $12(18 \%)$ \\
\hline $\mathrm{G} 2$ & $36(55 \%)$ \\
\hline $\mathrm{G} 3$ & $7(11 \%)$ \\
\hline No evaluation & $10(16 \%)$ \\
\hline \multicolumn{2}{|l|}{ Treatment methods: } \\
\hline $\mathrm{BCS}+\mathrm{RTH}$ & $5(8 \%)$ \\
\hline $\mathrm{BCS}+\mathrm{RTH}+\mathrm{CHTH}$ & $14(20 \%)$ \\
\hline $\mathrm{BCS}+\mathrm{RTH}+\mathrm{HTH}$ & $17(26 \%)$ \\
\hline$\underline{\mathrm{BCS}}+\mathrm{RTH}+\mathrm{CHTH}+\mathrm{HTH}$ & 27 (42\%) \\
\hline $\mathrm{BCS}+\mathrm{HTH}$ & $3(4 \%)$ \\
\hline
\end{tabular}

$B C S$ - breast conserving therapy, $R T H$ - radiotherapy,

CHTH - chemotherapy, HTH - hormonotherapy.
$P$-value $<0.05$ was considered statistically significant. This means that statistical difference was observed on the distinguished level of significance. The probability of survival without symptoms of the disease was estimated using the Kaplan-Meier method.

Based on individual, documented medical observations performed by the physicians from the Holycross Cancer Centre and the questionnaire developed at the Department of Radiotherapy, the intensity of late complications and the cosmetic outcome after treatment were assessed.

\section{Results}

The total observation time was from 105 to 143 months; median 113 months. Sixty-two (95\%) patients remain alive. Three patients died due to the metastases within 3 years after treatment. Recurrence of the disease was observed in $5(8 \%)$ patients. Distant metastases to the skeleton, lungs, and liver were the cause of death in 2 patients. In 1 case the cause of death was not defined.

In 2 patients, relapse occurred within the treated breast, which required the performance of a simple mastectomy. The patients who had undergone treatment due to local recurrence are alive. In one patient, cancer was diagnosed in the other breast. After surgical treatment (mastectomy) the patient is alive without recurrence. Based on the analysis of the Kaplan-Meier estimator of the survival function, it was found that the probability of 5-year survival without symptoms of the disease was $96.9 \%$, whereas the probability of 10 -year survival without symptoms of the disease was 95.3\% (Figure 1). No significant differences were observed between the groups of patients with and without cancer recurrence, according to the location of the tumour, receptor status, degree of clinical advancement, application of systemic treatment, radiotherapy, and hormonal therapy. The difficulty in the de-

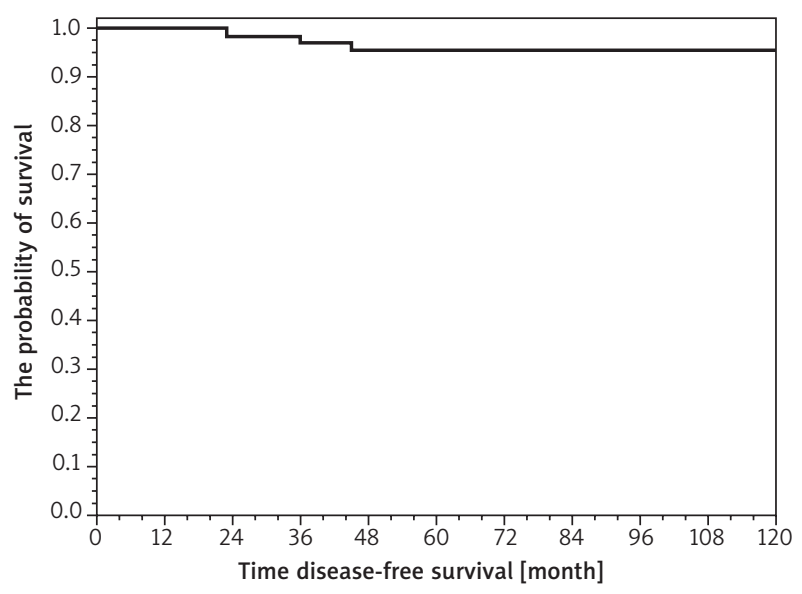

Figure 1. The probability of survival relative to disease-free survival of patients with breast cancer 
termination of factors responsible for the recurrence in the observed group of patients probably resulted from the small number of patients (5) in whom the relapse occurred. Based on observations from medical records and questionnaires completed by the patients, late toxicity of the combined treatment was also evaluated. As many as 32 (52\%) women in the study evaluated their general status and wellbeing after treatment as very good, 28 (43\%) - as good, and 2 patients - as poor. In 5 patients there occurred swelling of the arm at the surgical site; in 2 of them the breast and the regional lymphatic drainage area were irradiated. In the remaining patients, the circumference of the limb on the surgical site did not differ from that of the healthy limb. Six (9\%) patients reported pain complaints and limitation of shoulder joint mobility at the surgical site, whereas in the remaining patients these symptoms did not occur. The cosmetic outcome after treatment was also evaluated. The majority of patients - 58 (94\%) - evaluated the cosmetic outcome after the treatment as good or very good (Table 2).

\section{Discussion}

Breast-conserving therapy is a commonly used method of treatment in patients with breast cancer [9, 10]. At present, axillary lymphadenectomy is increasingly more rarely performed due to the introduction into clinical practice, within conserving therapy, of the method of determination of the sentinel lymph node [11-14]. In the group of patients analysed, the treatment was conducted in accordance with valid Polish recommendations. In all patients, cancer was diagnosed at stage I or II of clinical advancement. The correctness of the determination of the degree of advancement of cancer and qualification for this form of treatment were confirmed after obtaining the result of histological examination of the tissue material. All patients had quadrantectomy or lumpectomy, and axillary lymphadenectomy performed, levels I and II. In the case of indications for systemic treatment, radiotherapy was postponed until the completion of chemotherapy. This decision was made based on our own observations of patients after mastectomy, simultaneously treated by means of chemotherapy and radiotherapy, in whom intensified radiation-induced reactions were noted, even in the case of application of the CMF regimen. In patients with positive steroid hormonal receptors, hormonal therapy was initiated after completion of radiotherapy [15]. Radiotherapy was applied using the conformal techniques. Dosefractionation was performed in a classical way (50 Gy in 25 or 42.5 Gy in 17 fractions). The use of higher fractionation doses was associated with participation in a population study conducted by the Cancer Centre in Warsaw concerning the use of post-surgical radiotherapy within a shortened treatment time [16]. All patients were irradiated using the conformal tech-
Table 2. Cosmetic outcomes

\begin{tabular}{|lc|}
\hline Feature & $\boldsymbol{N}(\%)$ \\
\hline General condition: & $32(52)$ \\
\hline Very good & $28(45)$ \\
\hline Bad & $2(3)$ \\
Lymphoedema of the arm & $5(8)$ \\
$\begin{array}{l}\text { Pain or limited mobility in the } \\
\text { shoulder }\end{array}$ & $6(10)$ \\
Teleangiectases & $3(5)$ \\
Cosmetic effect: & $26(42 \%)$ \\
\hline Very good & $32(52 \%)$ \\
\hline Good & $4(6 \%)$ \\
\hline Bad & \\
\hline
\end{tabular}

nique, which allowed not only the administration of a homogeneous dose to the target area, but also assessment of the dose in healthy organs - heart and lungs. Nearly all patients (60) received an increased radiation dose to the tumour bed, which resulted in a reduction of risk of local recurrence $[17,18]$.

According to literature, after 10 years of observation, local failure in women treated in a combined way (surgical procedure, chemotherapy, radiotherapy) may occur in $10-15 \%$ of patients $[4,19,20]$.

In the analysed group, local recurrence occurred in $2(3 \%)$, and metastases in $3(5 \%)$ patients. The prognostic factors in patients with breast cancer are known [21, 22]. In the analysed group the prognostic factors were not determined due to the small size of the study group and the small number of recurrences.

An important element of conserving treatment is the cosmetic outcome. Literature reports show that the cosmetic outcome begins to stabilise 2-3 years after treatment, and does not change within a longer time of observation. The best cosmetic outcome is obtained after proper surgical treatment, preceded by the appropriate qualification of the patient. A small number of patients in the group analysed might be related with a cautious qualification for this management. The important factors that decide about the implementation of such a therapy are: patient decision and skills of the surgeon. Also, systemic therapy exerts an influence on the cosmetic outcome. In the reports by Johansen et al., in prospective studies, the effect of adjuvant chemotherapy and hormonal therapy on the cosmetic outcome was evaluated, as well as late complications after treatment $[23,24]$. In the opinion of these researchers, chemotherapy according to the CMF regimen may exert a negative effect on the cosmetic outcome and may be related to a higher percentage of skin changes (teleangiectases). Further on, the researchers indicate that irradiation of the re- 
gional lymph nodes may increase the percentage of patients in whom there occurred fibrosis of the breast. The percentage of patients in whom there occurred swelling of the upper limb on the surgical side in the analysed group was $8 \%$, which is a result close to the data from the literature $[23,25,26]$. Among other factors that may decide about late outcome of therapy are mentioned: age, scope of surgical treatment, and previously mentioned irradiation of the regional lymph nodes, or a combination of these factors [24, 27].

\section{Conclusions}

Long-term results of breast-conserving treatment of patients with early-stage breast cancer carried out in the Holycross Cancer Centre are good and are comparable to the data from the literature. Proper qualification of patients is very important for late cosmetic outcome. Distant complications occurred in a small number of patients, which shows the good quality of the combined treatment applied.

\section{Conflict of interest}

The authors declare no conflict of interest.

\section{References}

1. Fisher B, Jeong JH, Anderson S, Bryant J, Fisher ER, Wolmark N. Twenty-five-year follow up of randomized trial comparing radical mastectomy, total mastectomy and total mastectomy followed by irradiation. N Eng J Med 2002; 347: 567-75.

2. Fisher B, Redmond C, Fisher ER, Bauer M, Wolmark N, Wickerham DL, Deutsch M, Montague E, Margolese R, Foster R. Ten-year results of randomized clinical trial comparing radical mastectomy and total mastectomy with or without radiation. N Eng J Med 1985; 312: 674-81.

3. Arriagada R, Lê MG, Rochard F, Contesso G. Conservative treatment versus mastectomy - in early breast cancer: patients failure with 15 years of follow-up data. Institut Gustave- Roussy Breast Cancer Group. J Clin Oncol 1996; 14: 1558-64.

4. Fisher B, Anderson S, Bryant J, Margolese RG, Deutsch M, Fisher ER, Jeong JH, Wolmark N. Twenty-year follow up of randomized trial comparing total mastectomy, lumpectomy and lumpectomy plus irradiation for the treatment of invasive breast cancer. N Eng J Med 2002; 347: 1233-41.

5. Black DM, Hunt KK, Mittendorf EA. Long term outcomes reporting the safety of breast conserving therapy compared to mastectomy: 20-year results of EORTC 10801. Gland Surg 2013; 2: 120-3.

6. Zumsteg ZS, Morrow M, Arnold B, Zheng J, Zhang Z, Robson M, Traina T, McCormick B, Powell S, Ho AY. Breast conserving therapy achieves locoregional outcomes comparable to mastectomy in women with T1-2N0 triple negative breast cancer. Ann Surg Oncol 2013; 20: 3469-76.

7. Kułakowski A, Towpik E. Zasady rozpoznawania i leczenia nowotworów zalecane przez Centrum Onkologii w Warszawie. PFESO 1997; 107-20.

8. Krzakowski M (ed.) Zalecenia postępowania diagnostyczno-terapeutycznego $\mathrm{w}$ nowotworach złośliwych u dorosłych. PUO 2003; 107-40.
9. Early Breast Cancer Trialists Collaborative Group (EBCTCG); Darby S, McGale P, Correa C, Taylor C, Arriagada R, Clarke M, Cutter D, Davies C, Ewertz M, Godwin J, Gray R, Pierce L, Whelan T, Wang Y, Peto R. Effect of radiotherapy after breast conserving surgery on 10-year recurrence and 15-year breast cancer death: meta-analysis of individual patient data for 10801 women in 17 randomised trials. Lancet 2011; 378: 1707-16.

10.van der Sangen MJ, Poortmans PM, Nieuwenhuijzen GA, Roukema JA, Roumen RM, Tjan-Heijnen VC, Voogd AC. Local recurrence following breast conserving treatment in women aged 40 years or younger: trends in risk and the impact on prognosis in a population-based cohort of 1143 patients. Eur J Cancer 2013; 49: 3093-101.

11. Ho A, Morrow M. The evolution of the locoregional therapy of breast Cancer. Oncologist 2011; 16: 1367-79.

12. Reimer T, Hartmann S, Stachs A, Gerber B. Local treatment of the axilla in early breast cancer: concepts from National Surgical Adjuvant Breast an Bowel Project B-04 to the Planned Intergroup Sentinel Mamma Trial. Breast Care 2014; 9: 87-95.

13. Wazir U, Manson A, Mokbel K. Towards optimal management of the axilla in the context of a positive sentinel node biopsy in early breast cancer. World J Clin Oncol 2014; 5: 792-4.

14. Warren LE, Punglia RS, Wong JS, Bellon JR. Management of the regional lymph nodes following breast-conservation therapy for early-stage breast cancer: an evolving paradigm. Int J Radiat Oncol Biol Phys 2014; 90: 772-7.

15. Bentzen SM, Skoczylas JZ, Overgaard M, Overgaard J. Radiotherapy-related lung fibrosis enhanced by tamoxifen. J Natl Cancer 1996; 88: 918-22.

16. Gałecki J, Bujko K, Grudzień-Kowalska M, Hicer-Grzenkowicz J, Załucki W, Niwińska A, Kukołowicz P, Michalski W. Preliminary results of adjuvant radiotherapy in breast cancer patients using shortened overall treatment time - a population study. Nowotwory J Oncol 2007; 57: 20-8.

17. Jones HA, Antonini N, Hart AA, Peterse JL, Horiot JC, Collin F, Poortmans PM, Oei SB, Collette L, Struikmans H, Van den Bogaert WF, Fourquet A, Jager JJ, Schinagl DA, Wárlám-Rodenhuis CC, Bartelink H. Impact of pathological characteristics on local repalse after breast-conserving therapy; a subgroup analysis of the EORTC boost versus no boost trial. J Clin Oncol 2009; 27: 4939-47.

18. Bartelink H, Maingon P, Poortmans P, Weltens C, Fourquet A, Jager J, Schinagl D, Oei B, Rodenhuis C, Horiot JC, Struikmans H, Van Limbergen E, Kirova Y, Elkhuizen P, Bongartz R, Miralbell R, Morgan D, Dubois JB, Remouchamps V, Mirimanoff RO, Collette S, Collette L; European Organisation for Research and Treatment of Cancer Radiation Oncology and Breast Cancer Groups. Whole breast irradiation with or without a boost for patients treated with breast-conserving surgery for early breast cancer: 20 -year follow-up of randomised phase 3 trial. Lancet Oncol 2015; 16: 47-56.

19. Fowble B. Ipsilateral breast tumor recurrence following breast-conserving surgery for early-stage invasive cancer. Acta Oncologica 1999; 38 Suppl 13: 9-17.

20.Jacobson JA, Danforth DN, Cowan KH, d'Angelo T, Steinberg SM, Pierce L, Lippman ME, Lichter AS, Glatstein E, Okunieff $P$. Ten years results of comparison of conservation with mastectomy in the treatment of stage I and II breast cancer. N Eng J Med 1995; 332: 907-11. 
21. Fitzgibbons PL, Page DL, Weaver D, Thor AD, Allred DC, Clark GM, Ruby SG, O’Malley F, Simpson JF, Connolly JL, Hayes DF, Edge SB, Lichter A, Schnitt SJ. Prognostic factors on breast cancer: College of American Pathologists Consensus Statement 1999. Arch Pathol Lab Med 2000; 124: 966-78.

22. Kim KJ, Huh SJ, Yang JH, Park W, Nam SJ, Kim JH, Lee JH, Kang SS, Lee JE, Kang MK, Park YJ, Nam HR. Treatment results and prognostic factors of early breast cancer treated with breast conserving operation and radiotherapy. Jpn J Clin Oncol 2005; 35: 126-33.

23.Johansen J, Overgaard J, Blichert-Toft M, Overgaard M. Treatment morbidity associated with the management of the axilla in breast-conserving therapy. Acta Oncologica 2000; 39: 349-54.

24. Johansen J, Overgaard J, Overgaard M. Effect of adjuvant systemic treatment on cosmetic outcome and late normaltissue reactions after breast conservation. Acta Oncologica 2007; 46: 525-33.

25. Niwińska A, Tchórzewska H, Procner M, Kraszewska E. The frequency and risk of developing lymphedema of the upper extremity after breast conserving surgery. Nowotwory J Oncol 2005; 55: 213-8.

26. Pawlaczyk A, Kornafel J. Evaluation of the influence of therapeutic factors on the cosmetic outcomes of conservative treatment of patients with breast carcinoma. Nowotwory J Oncol 2005; 55: 226-34.

27. Olivotto IA, Rose MA, Osteen RT, Love S, Cady B, Silver B, Recht A, Harris JR. Late cosmetic outcome after conservative surgery and radiotherapy: analysis of causes of cosmetic failure. Int J Radiat Oncol Biol Phys 1989; 17: 743-53.

\section{Address for correspondence:}

Piotr Kędzierawski MD, PhD

Clinic of Radiotherapy

Holycross Cancer Centre

ul. Artwińskiego 3, 25-734 Kielce, Poland

Phone: +48 609211933

E-mail: piotrkedzierawski@wp.pl 